\title{
Hidden paintings, forgotten histories: a micro-stratigraphic approach to study coated rock art
}

\author{
Lucas Gheco ${ }^{1,2}$ (1) $\cdot$ Marcos Tascon ${ }^{1,3} \cdot$ Marcos Gastaldi $^{4} \cdot$ Eugenia Ahets Etcheberry $^{5} \cdot$ Soledad Pereda $^{6}$. \\ Noemi Mastrangelo ${ }^{1} \cdot$ Marcos Quesada $^{2,7} \cdot$ Fernando Marte $^{1}$
}

Received: 11 December 2018 / Accepted: 6 May 2019

(C) Springer-Verlag GmbH Germany, part of Springer Nature 2019

\begin{abstract}
Is it possible to detect rock paintings coated by natural or anthropic concretions? In this work, a methodology to discover and characterize underlying paintings is proposed. This approach combines chemical studies by micro-Raman and SEM-EDS of micro-stratigraphic samples taken from the paintings and support rock. As a case of study, it is described the research performed in the archeological site of Oyola in the northwest of Argentina. Strong evidences of red, black, and white hidden paintings have been found. In addition, the method herein presented is thoroughly evaluated pointing out their possibilities and limitations as a tool for the understanding of the historical processes involving production and transformation of the rock art panels. To this end, the methodology was proofed to be a successful exploratory approach for painting detection, expanding its capabilities when complemented with non-invasive characterization techniques.
\end{abstract}

Keywords Rock art $\cdot$ Archeology $\cdot$ Raman spectroscopy $\cdot$ Hidden paintings

\section{Introduction}

When studying rock art, only a small portion of the paintings and engravings on the rock are uncovered to the bare eyes. Multiple factors erode rock's surfaces, and consequently destroy the figures, but also some processes deposit thin layers that cover rock art hiding the paintings. As an example of these processes can be mentioned the natural formations of calcium oxalate crusts (Chiriu et al. 2014; Edwards et al. 1997; A Hernanz et al. 2007; Antonio Hernanz et al. 2014;

Electronic supplementary material The online version of this article (https://doi.org/10.1007/s12520-019-00854-z) contains supplementary material, which is available to authorized users.

Lucas Gheco

gheco@hotmail.com

1 Instituto de Investigaciones sobre el Patrimonio Cultural (IIPC-TAREA), Universidad Nacional de San Martín, Benito Quinquela Martín 1784, Buenos Aires, Argentina

2 Centro de Investigaciones y Transferencia Catamarca (CONICET-UNCa), Prado 366, S. F. V., de Catamarca, Argentina

3 Instituto de Investigación e Ingeniería Ambiental (3iA), Universidad Nacional de San Martín (UNSAM), San Martín, Buenos Aires, Argentina
Roberts et al. 2015; Ruiz et al. 2012), calcium carbonate layers (Dirk L Hoffmann et al. 2016; Guilhem Mauran et al. 2019), manganese-iron oxide deposits from microorganism activities (Šebela et al. 2015), bat or pack-rat guano (Hill 1982), and other mineral accretions (Green et al. 2017). Alternatively, anthropic actions produce similar layers that could overlap and hide paintings such as soot deposits (L. Gheco et al. 2017; Tascon et al. 2016; Vandevelde et al. 2017a; Vandevelde et al. 2017b), cooking residues (Steelman et al. 2002), and tar due to the use of torches (Medina-Alcaide
4 Instituto de Antropología, Consejo Nacional de Investigaciones Científicas y Técnicas, Museo de Antropología, Av. Hipólito Irigoyen 174, Córdoba, Argentina

5 Facultad de Filosofía y Letras, Universidad de Buenos Aires, Puan 480, Buenos Aires, Argentina

6 Instituto Nacional de Tecnología Industrial, Av. General Paz 5445, Buenos Aires, Argentina

Escuela de Arqueología, Universidad Nacional de Catamarca, Av. Belgrano 300, S. F. V., de Catamarca, Argentina 
2015; Šebela et al. 2015; Zupančič et al. 2011). Therefore, the question is: can rock paintings exist under these natural or anthropic layers? How can they be detected?

In order to address this issue, some spectroscopic techniques such as infrared photography (Fredlund and Sundstrom 2007) or digital enhancement software have been explored (Harman 2008; Quesada Martínez 2010). Some of these techniques are able to optically detect, under certain conditions, underlying layers allowing, in this way, to capture hidden images below biodegradation or anthropic layers. However, in the case of the spectroscopic techniques, since the absorption of the specific radiation depends on the nature of the unknown materials, the odds of success are quite limited and unpredictable. For instance, when using infrared photography, the presence of high concentrations of carbon in the layers, such as soot deposits, interferes with the detection of possible paints below due to high infrared absorption.

This paper aims to present a methodological alternative that combines micro-stratigraphic observations and chemical studies to detect and characterize anthropic subjacent layers which are not visible. In this manner, it can be inferred the presence of underlying motifs and, by this, add another episode to the historical process of painting on the walls. This methodology is based on the analysis of micro-samples taken from mural paintings and rock surfaces inside the caves. After a careful process of sample preparation and inclusion, they were observed in a stratigraphic view and then analyzed by Raman spectroscopy and scanning electron microscopy with energydispersive spectroscopy (SEM-EDS). As a case of study, we present the results obtained from rock art's caves of Oyola, an archeological site situated in the northwest of Argentina. There, after the analysis of more than a hundred samples, we proposed the presence of subjacent motifs even when no classical photographic records gathered visual evidence. In this context, several criteria are established in order to comprehensively characterize the nature of the subjacent stratum as a painting layer including archeological, historical, chemical, and physical information. To this end, it is important to highlight that the methodology herein proposed is not only restricted to this case but could also be applied to the study of many other sites with similar characteristics.

\section{The archeological site of Oyola}

The site of Oyola is located in the El Alto-Ancasti's mountain at the eastern side of Catamarca Province, Argentina (Fig. 1). The earliest reports from Oyola were published by Amalia Gramajo and Hugo Martínez Moreno in 1978 and 1982, respectively (Gramajo and Martínez Moreno 1978, 1982). They described eight caves with paintings and engravings placed on the base of huge granitic rocks that are part of a batholith of $2.5 \mathrm{~km}$ of diameter. As most of the rock art from this area, the figures from Oyola were attributed to La Aguada culture (ca. $500-1000$ d.C.) as a result of the similarities between the paintings with the traditional pottery designs linked with this culture (De la Fuente et al. 2005; González 1998; Gordillo et al. 2000; Segura 1988). Since 2008, our research team continues with the documentation of the site discovering new shelters with rock art in the middle of the dense forest characteristic of the region. Up to date, a total of 38 caves with paintings and engravings have been localized (Lucas Gheco 2017; Quesada et al. 2016).

The rock art of Oyola exhibits a great diversity of forms, colors, sizes, and spatial arrangements (Fig 1Supplementary materials) (Lucas Gheco 2012; Lucas Gheco and Quesada 2012). Although the number of figures discovered in the caves is continuously growing, the preliminary survey of the entire site - 38 caves - shows at least, the presence of 400 motifs, mostly painted except some cases of engraving. Essentially, this diversity is a consequence of many painting events that produced and transformed the rock art's panels over time. The presence of overlapped figures and the stylistic and chemical variability between painting mixtures are some of the reasons that support the hypothesis of complex making processes with multiple stages of painting production, perhaps temporally distanced from the La Aguada period (L. I. Gheco et al. 2013; Lucas Gheco 2017; Quesada and Gheco 2015). This hypothesis expands the chronological limits of the investigations and inquires the accepted cultural attributions performed in the region. More important, this hypothesis also allowed us to center the attention in the historical process of production and its complexities, even within the limits of $\mathrm{La}$ Aguada culture. In this way, the research focuses moves from a general cultural attribution to an exploration of the construction processes, modifications, and uses of the rock art in different historical moments. Nevertheless, some parts of these paint's histories remain hidden behind different layers of natural or anthropic origins.

\section{Oyola's chemical analysis of rock paintings}

In the last years, our studies in Oyola were focused on the application of different methods and techniques of chemical analysis in order to understand the materials employed to make the paints. Firstly, we made bulk analyses to study 18 samples by X-ray diffraction (XRD), Fourier transform infrared spectroscopy (FT-IR), and X-ray fluorescence (XRF) (Lucas Gheco 2017; Lucas Gheco and Poliszuk 2015). These samples were taken from the rock art figures and from the rock surface without paintings. But the difficulties in these studies to discern the materials corresponding to the paint mixtures from the components of the rock support or possible natural crusts pushed us to adopt other method of analysis. Then, for this reason, we used a more detailed method of 
Fig. 1 Archeological sites with pre-Hispanic rock art at the Ancasti's mountain, Province of Catamarca, northwest of Argentina

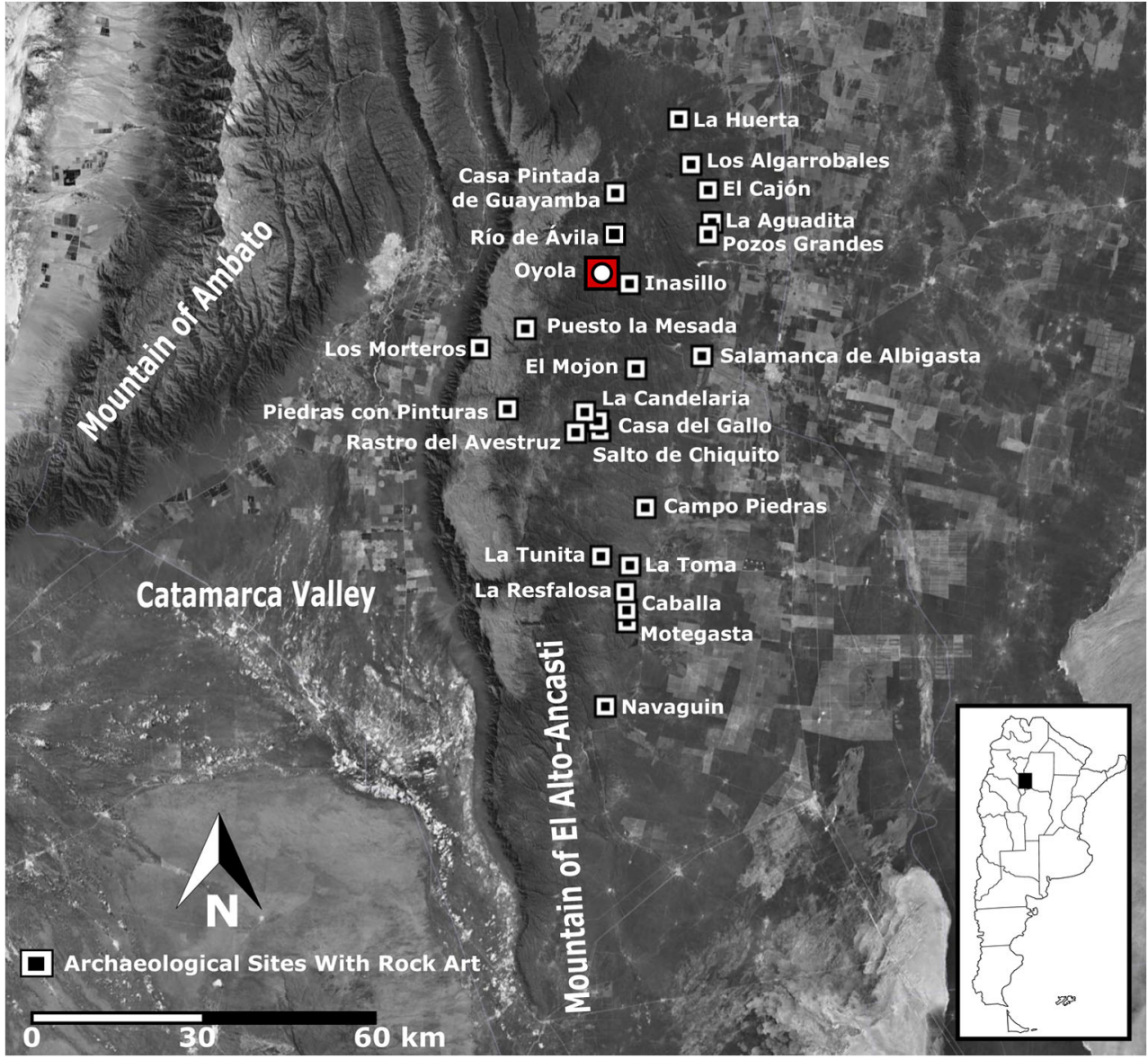

micro-stratigraphic characterization (Marte et al. 2011, 2013) and studied 151 samples taken from 21 caves at Oyola's site. Although samples were taken from different places, as a proof of concept, we centered the research in the cave named Oyola 7, where we took 66 samples considering paints, natural or anthropic depositions, and rock support. Besides, this cave has been deeply studied in prior works (Lucas Gheco 2012, 2017) and the floor has been exhaustively excavated (Gastaldi et al. 2016).

The results obtained in the micro-stratigraphic analyses, plus the information of the bulk studies, allow us to characterize, firstly, the granitic rock support where the paints were done. Analyses by Raman and FT-IR of the rock show the characteristic peaks of quartz, gypsum, and calcium oxalates in the form of whewellite or weddellite (Edwards et al. 2000; Feliu and Martínez-Brell 2008; A Hernanz et al. 2007; Trujillo et al. 2010). These components were also detected by XRD and are in agreement with the elemental analysis by SEMEDS and XRF (Lucas Gheco and Poliszuk 2015). Although the presence of quartz is normal in this type of igneous felsic rock, the detection of gypsum and calcium oxalates must be interpreted as the result of formation layers that cover the rock. The natural origin of whewellite and weddellite has been widely studied and it is explained as the reaction of calcareous components present in the rock surface, such as calcite, with oxalic acid derived from the metabolic activities of microflora, such as cyanobacteria and lichens (A Hernanz et al. 2007; Roberts et al. 2015; Ruiz et al. 2012; Russ et al. 1999; Tascon et al. 2016; Watchman 1991). Similarly, the gypsum could be interpreted as a natural product of lichen catalysis of sulfate ions in unpolluted or only slightly polluted environments (Prieto et al. 1998) or as a consequence of the reaction of the calcareous components of the rock with high levels of gaseous sulfur oxide produced by volcanic activity (Tomasini et al. 2013).

In the same way, chemical analyses allow us to detect main inorganic components of the paintings. The red mixtures exhibited characteristic spectra of hematite when Raman and FTIR analyses were performed. Besides, gypsum and whewellite or weddellite were also found in most of the samples. In addition, XRD allowed us to also identify some clays, such as illite. The white paints present high levels of calcium by SEMEDS and XRF due to the presence of gypsum and, in some samples, calcium carbonate, both detected by Raman and FTIR. These samples, as well as the red and black paints, evidenced the presence of whewellite or weddellite. Finally, all the black paintings analyzed present the peaks of carbon as the main pigment. 
Table 1 Summary of the studied caves and samples taken

\begin{tabular}{|c|c|c|c|c|}
\hline Cave & No. of motifs & No. of samples taken from paintings & No. of samples taken from alteration deposits & Total samples \\
\hline Oyola 1 & 17 & 5 & 2 & 7 \\
\hline Oyola 2 & 6 & 0 & 1 & 1 \\
\hline Oyola 4 & 1 & 1 & 1 & 2 \\
\hline Oyola 5 & 9 & 3 & 0 & 3 \\
\hline Oyola 6 & 46 & 5 & 7 & 12 \\
\hline Oyola 7 & 76 & 32 & 34 & 66 \\
\hline Oyola 8 & 6 & 1 & 2 & 3 \\
\hline Oyola 9 & 5 & 1 & 0 & 1 \\
\hline Oyola 10 & 5 & 1 & 0 & 1 \\
\hline Oyola 11 & 12 & 3 & 0 & 3 \\
\hline Oyola 12 & 4 & 8 & 0 & 8 \\
\hline Oyola 13 & 24 & 1 & 1 & 2 \\
\hline Oyola 14 & 29 & 3 & 1 & 4 \\
\hline Oyola 17 & 12 & 3 & 2 & 5 \\
\hline Oyola 19 & 6 & 2 & 0 & 2 \\
\hline Oyola 24 & 9 & 0 & 1 & 1 \\
\hline Oyola 26 & 11 & 2 & 0 & 2 \\
\hline Oyola 30 & 9 & 1 & 0 & 1 \\
\hline Oyola 22 & 3 & 0 & 1 & 1 \\
\hline Oyola 34 & 45 & 22 & 3 & 25 \\
\hline Oyola 35 & 5 & 0 & 1 & 1 \\
\hline Totals & 94 & 57 & 151 & \\
\hline
\end{tabular}

In this context, observations of some micro-stratigraphic samples taken from paintings and soot layers, which cover the walls of some caves at Oyola, exhibit the presence of thin layers placed under the stratum that correspond to the visible figures or soot deposit sampled. These underlying layers present different colors than the sampled figures/deposit, so we proposed as a hypothesis that could be the relic of older paintings or ground support covered by other natural or cultural stratum. In the following sections, we describe a method to chemically and physically detect and characterize these possible underlying paintings coated by multiple layers that prevent the direct visualization of the motif.

\section{Materials and methods}

A total of 151 samples were taken from the paintings and rock support, especially from the black deposits that cover the walls of some caves. Table 1 summarizes the number of samples taken as well as the sampling sites and origins (painting or alteration deposits).

Furthermore, the extraction strategy employed consisted of two main stages: (1) An exhaustive documentation of the painted walls and a sampling from panels where, after the natural peeling of the most external layers, it was able to see underlying layers of red, white, or black color. (2) Since the preliminary chemical analyses showed that the soot deposits were the most usual coating of the paintings, the observations and sampling were focused in these darker areas.

The method used for the micro-stratigraphic analysis is based on previous protocols that comprehended different stages before, during, and after sampling (Lucas Gheco 2017; Tascon et al. 2016). The samples of about $1 \mathrm{~mm}^{2}$ were taken using a scalpel and binocular lenses (OptiVISOR, Donegan Optical Company, USA) for deeper precision and were stored in 1.5-mL-capacity Eppendorfs. Later, each sample was included in acrylic resin (Subiton®); thus, its transversal section is exposed perpendicularly to the field of view. Then, the samples were polished with sandpaper of different granulometry. Observation and photography of the samples were achieved using a DM EP Leica microscope (visible and ultraviolet light sources were used in normal and polarized modes). Images were recorded using a Leica DFC280 digital camera and processed with Leica Application Suite 4.0 software in order to document general and particular aspects of the stratigraphies. The included samples were analyzed by micro-Raman spectroscopy using a Lab RAM HR UV-Vis-NIR (Horiba Jobin Yvon) spectrograph equipped with two monochromator gratings and a charge-coupled device detector. A grating of $1800 \mathrm{~g} / \mathrm{mm}$ and a hole of $100 \mathrm{~mm}$ 


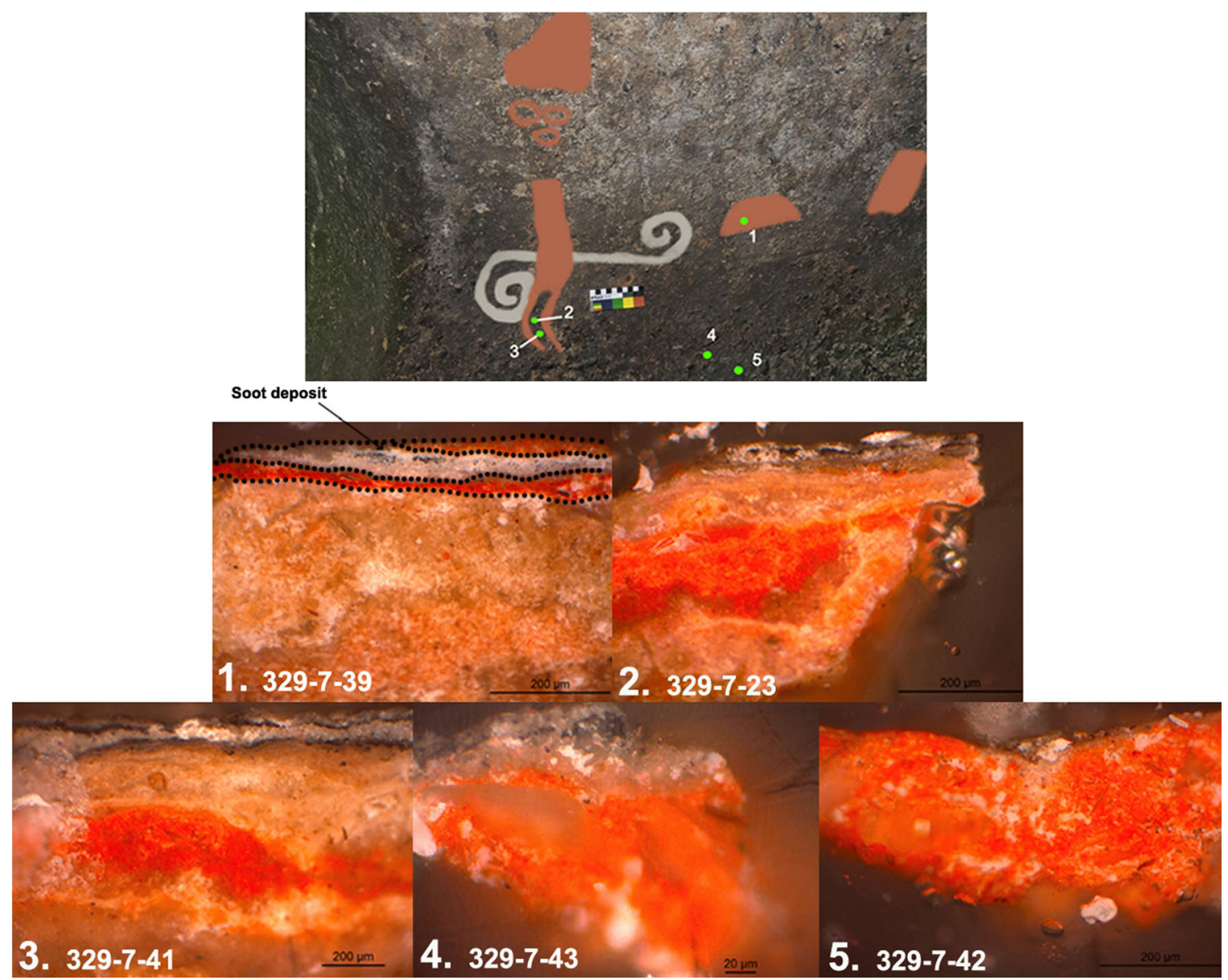

Fig. 2 Rock paintings at panel B of Oyola 7 (digitally traced) with the sampled points. Below, micro-stratigraphies of the samples taken from the paints and soot deposit of this panel

resulted in spectral resolution of $1.5 \mathrm{~cm}^{-1}$. The spectrograph was coupled to a microscope with $\times 10, \times 50$, and $\times 100$ magnifications. Laser line at $514 \mathrm{~nm}$ (Ar+laser) was used as the excitation source and filtered to ensure power density was low enough to avoid sample overheating. Typically, for a $\times 50$ magnification, spot diameter was about 2-3 $\mu \mathrm{m}$. Also, the samples were observed and analyzed using a microscope scanning electron Philips SEM 505 obtaining the photomicrographs, mappings, and corresponding spectra. Samples were metalized with gold.

\section{Results}

\section{Red underlying layers}

After the observation of the samples taken from Oyola's caves, we could affirm that the micro-stratigraphies analyzed do not present red layers containing hematite unless samples were taken from red paintings. Beyond our experimental results, to the best of our knowledge, there are no reports of red strata formation as a consequence of natural processes in the zone. This implies that there are no natural depositions with these features in the caves of the site.

However, some samples taken from dark soot layers and from painting motifs of other colors exhibit underlying reddish layers that vary between intense reds and lighter oranges. As an example, in panel B of the cave Oyola 7, we took 5 samples, 1 from a red painting and the others from the black soot that covers the rock surface in the surrounding area (Fig. 2). In this panel, we could see a red figure with anthropomorphic features (legs, eyes, mouth) that overlap a white lineal motif with spiral ends. Near, other geometric red paintings could be interpreted as the relicts of ancient pictures nowadays deteriorated. However, as we see in the cross sections, some reddish strata discovered under the superficial ones allow us to think that other red paintings remain hidden below the soot stratum.

The SEM-EDS analyses performed on the red underlying layers revealed the presence of iron, calcium, sulfur, silicon, and aluminum as major elements. Raman studies exhibited the characteristic bands of hematite $\left(\mathrm{Fe}_{2} \mathrm{O}_{3}\right)$ in 224, 244, 292, 409, and $610 \mathrm{~cm}^{-1}$ and, in some cases, also confirmed the presence of gypsum $\left(\mathrm{CaSO}_{4} \cdot 2 \mathrm{H}_{2} \mathrm{O}\right)$ evidencing characteristic bands at 


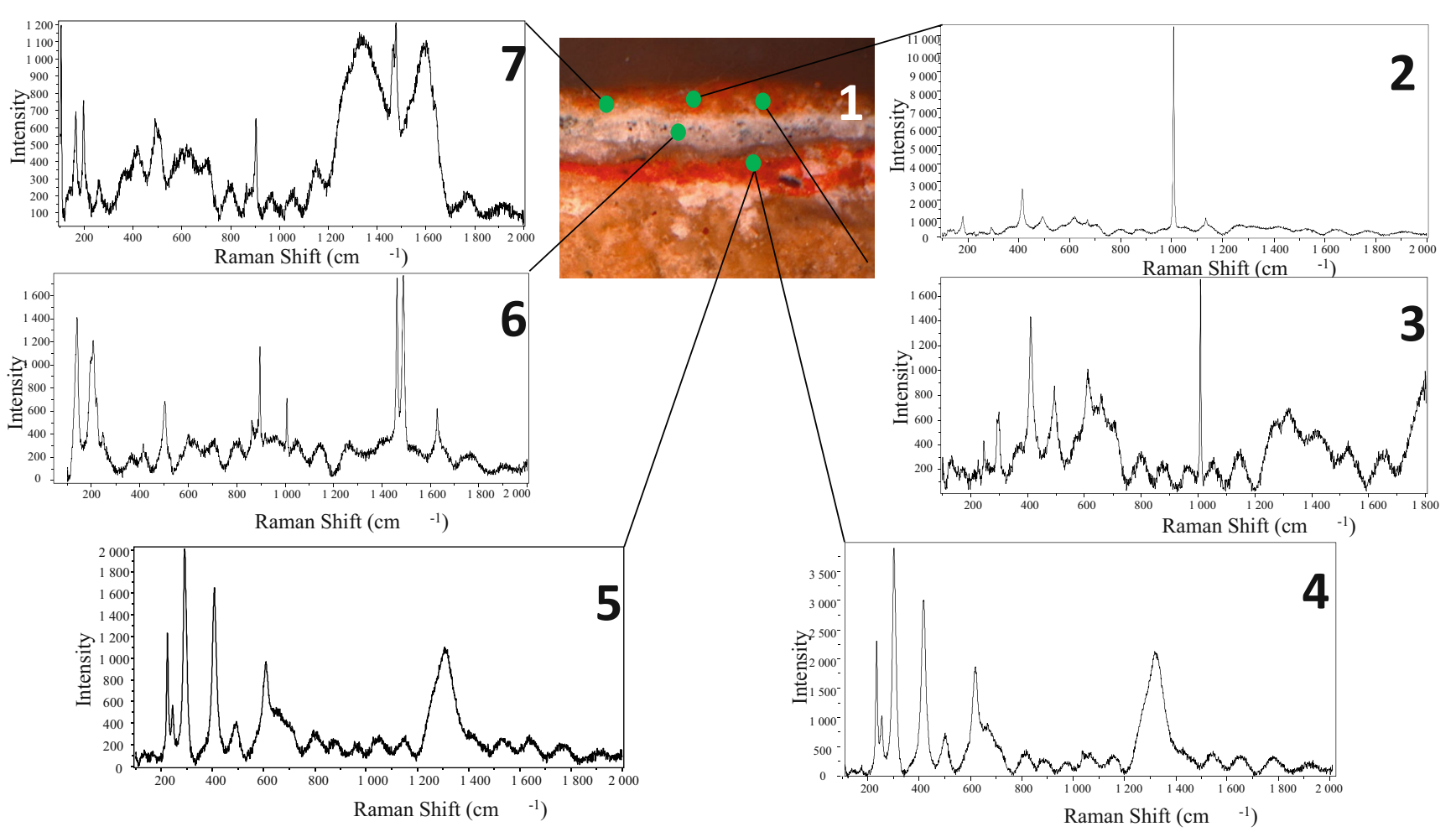

Fig. 3 Raman analyses of sample 1 at panel B of Oyola 7. Each spectrum exposes the characteristic bands of (2) gypsum and hematite, (3) gypsum and hematite, (4) hematite, (5) hematite, (6) gypsum and whewellite, and (7) carbon and whewellite

140, 181, 493, 619, 1007, and $1132 \mathrm{~cm}^{-1}$ (A Hernanz et al. 2007; Antonio Hernanz et al. 2008, 2016; Ruiz et al. 2012). In general terms, the composition of the red underlying stratum is similar in all cases to the composition of the red paintings sampled from visible figures.

As an example, sample 329-7-39 (sample 1 in Fig. 2) taken from a red motif of panel B (Fig. 3) is shown. The microstratigraphy displays, at least, four different layers. The first, starting from the top, presents an orange color and could be attributed to the stratum that corresponds to the sampled visible painting. Raman analysis of this layer displays the characteristic bands of hematite and gypsum. The second white layer exhibits the presence of whewellite $\left(\mathrm{Ca}\left(\mathrm{C}_{2} \mathrm{O}_{4}\right) \cdot\left(\mathrm{H}_{2} \mathrm{O}\right)\right)$, gypsum, and some carbon particles. Below, the third stratum presents a thin and black appearance and could be attributed to a soot deposit produced by the hearths lighted near the wall and also detected in other samples of this panel (Tascon et al. 2016). The fourth layer also displays a red color, but in this case darker and more intense than the previous one. The Raman analysis reveals only the presence of hematite. The morphology and the chemical composition of this layer are similar to some of the red figures studied in Oyola. Finally, the last stratum corresponds to the rock support. In the same way, mapping obtained in SEM-EDS reinforces this interpretation and shows the elemental concentration characteristics of each component (Fig. 4). The differences of Fe concentration between the first and the fourth layer could be attributed to a mixture with less quantity of hematite and the use of higher concentrations of gypsum as filler in the most external paint layer. These results are complemented by those obtained by Raman spectroscopy where both components were evidenced. In addition, the most external layer corresponds to a visible red figure so the natural origin of the stratum must be discarded.

Therefore, having all this evidence in mind, we can postulate the presence of possible red painting layer below the most recent one. The latter can be attributed to either a completely new artwork or a restoration event where the original figure is conserved but the surface is repainted, among other possibilities. The thickness of some natural strata as gypsum or whewellite could be an indicator of the temporal distance between the painting events and, in this way, a possible evidence to evaluate the mentioned cultural hypothesis.

Other similar cases have been studied in samples taken from this and other caves at Oyola. In Fig. 5, reddish layers located directly under black soot deposits or below thick layers of calcium oxalates can be seen. These layers present the same morphological characteristics and chemical composition with the red paintings described. For example, a sample taken from the other cave of the site (Oyola 6) exposes the Raman signals of hematite in the red stratum under a black deposit of soot. It is important to note that in another sample 
Fig. 4 SEM-EDS mapping of sample 1 from panel B of Oyola 7. The images show the concentration of chemical elements $(\mathrm{C}, \mathrm{Fe}, \mathrm{S}, \mathrm{Ca}, \mathrm{Al}, \mathrm{Si}$, and $\mathrm{P})$ in the sample

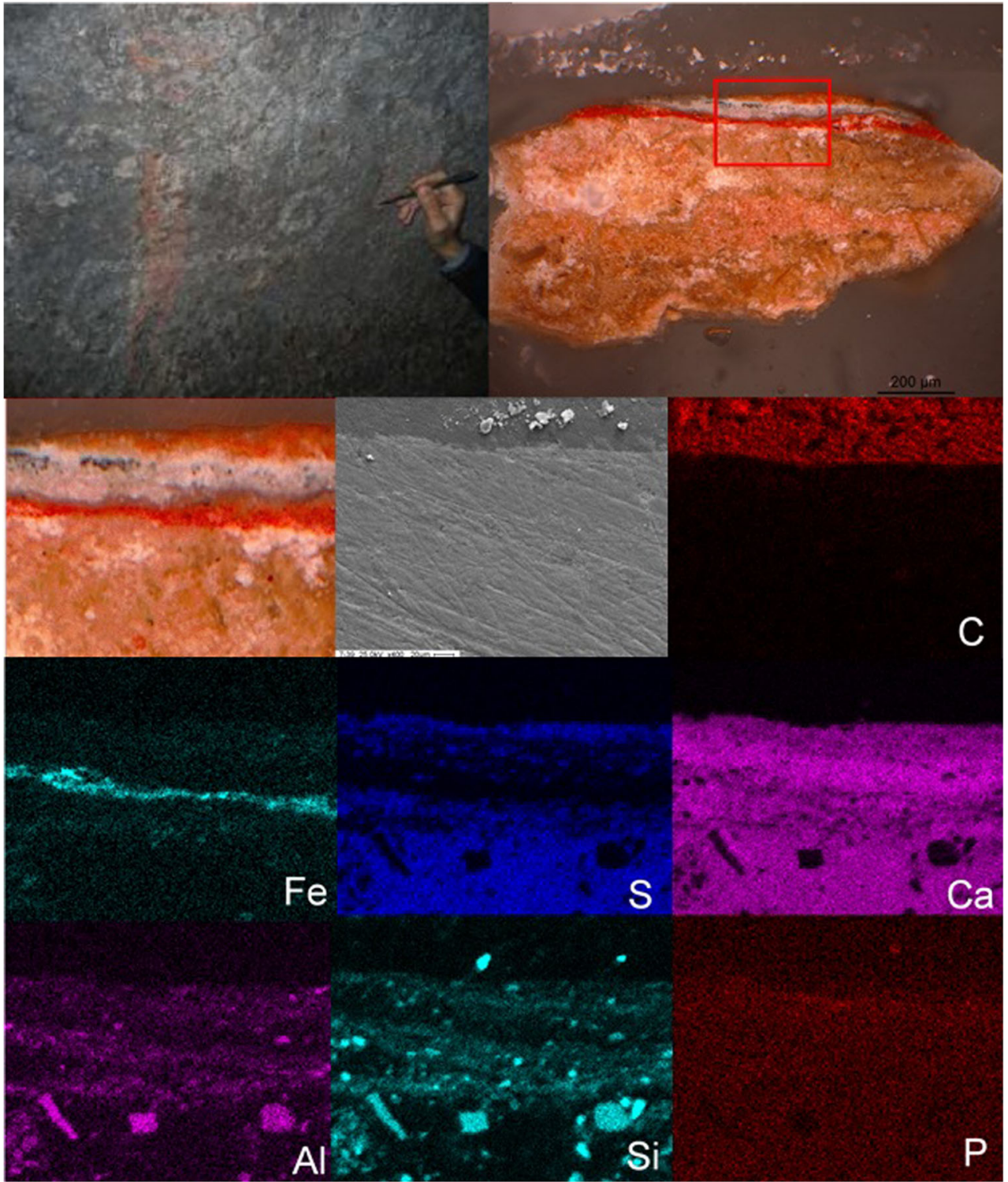

taken from the same panel but few centimeters away, the red layers do not appear, supporting the underlying painting hypothesis (Fig. 6).

\section{Black underlying layers}

The research of possible black paintings hidden at the Oyola's caves presents several challenges. As we previously reported, after the analysis of 47 micro-stratigraphic samples taken from 8 different caves, a method was developed to reliably identify and characterize thin soot layers deposited by lighted hearths inside the shelters (Gastaldi et al. 2016; Tascon et al. 2016). The soot layers present a carbonaceous composition that is similar to the pigments used in the black rock paintings, so now the problem lies not only in the discovery of black underlying strata but also in the differentiation between paints and soot layers. This problem could be addressed by considering not only the chemical information but also physical properties related to the deposition origin such as stratum thickness or heterogeneity, particle size, and shape. After careful measurement of micro-stratigraphic layers of known painting black layers and soot deposits, we found statistically significant differences between both groups. For such purpose, a two-tailed $t$ test was performed assuming different variances between groups and a significance of 0.05 . The value of $P$ was 0.029 which means that both groups are different. Particularly, stratum thickness and heterogeneity showed the most interesting results. For painting layers, the strata showed an average thickness of $38.5 \mu \mathrm{m}$ with a standard deviation of 23.5 which indicates a great heterogeneity (coefficient of variation $61 \%$ ). On the other hand, the soot layers exhibited an average of $16 \mu \mathrm{m}$ with a standard deviation of 4 (coefficient of variation 


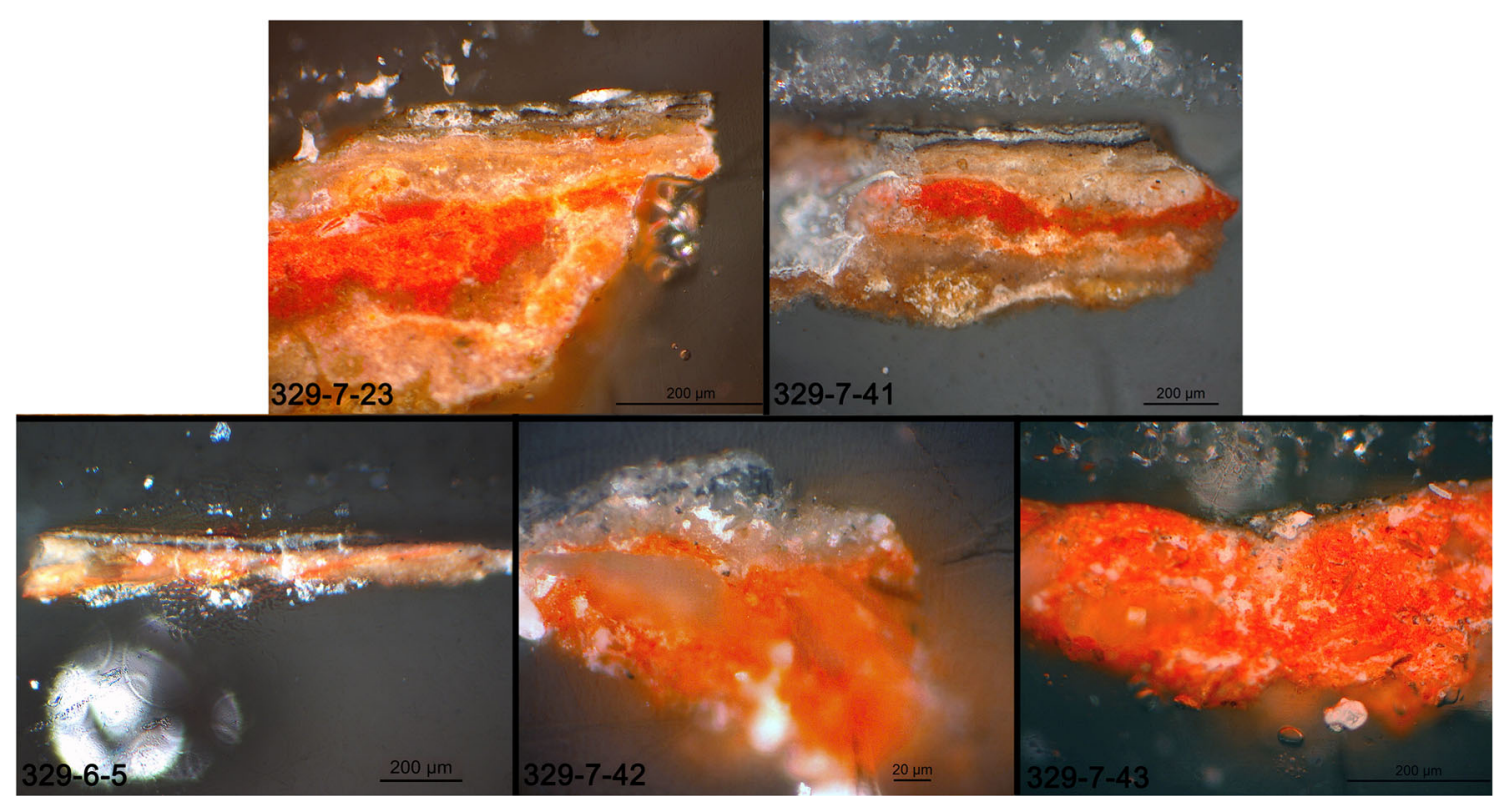

Fig. 5 Micro-stratigraphies of the samples with underlying red paintings detected at caves Oyola 6 (329-6-5) and Oyola 7 (329-7-23, 329-7-41, 329-742, 329-7-43)

$25 \%)$. Besides, although the particle size is a potential marker, the results are not conclusive while the particle shape seems to play an important role in the characterization. The soot particles present a relative homogeneous acicular shape very different than the irregular form of the charcoal particles observed in paints (please see supplementary information).

As an example of the difficulties of detecting and interpreting the underlying black layers, we could describe
Fig. 6 Micro-stratigraphies of the samples taken from Oyola 6 and photograph of the cave

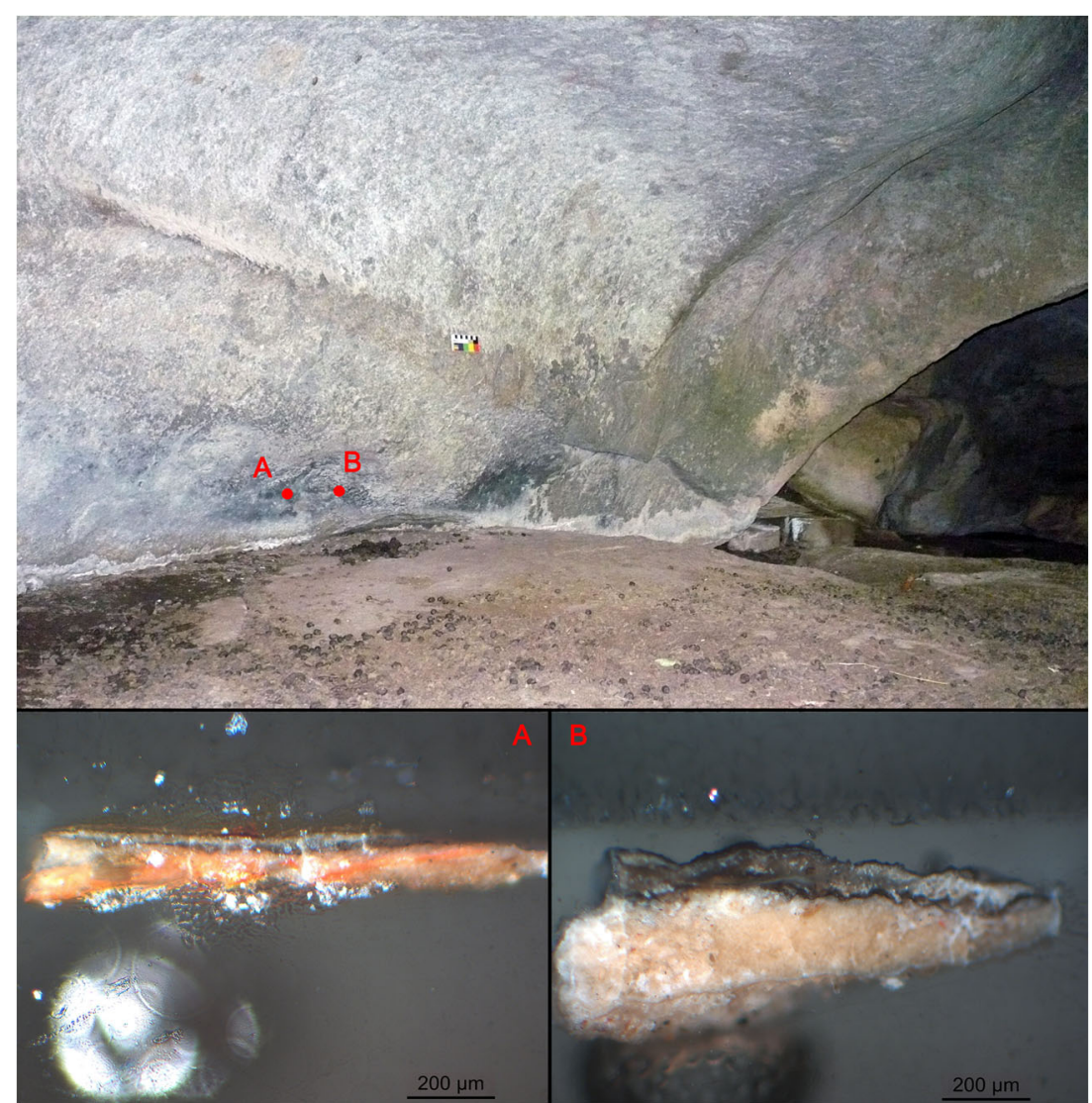




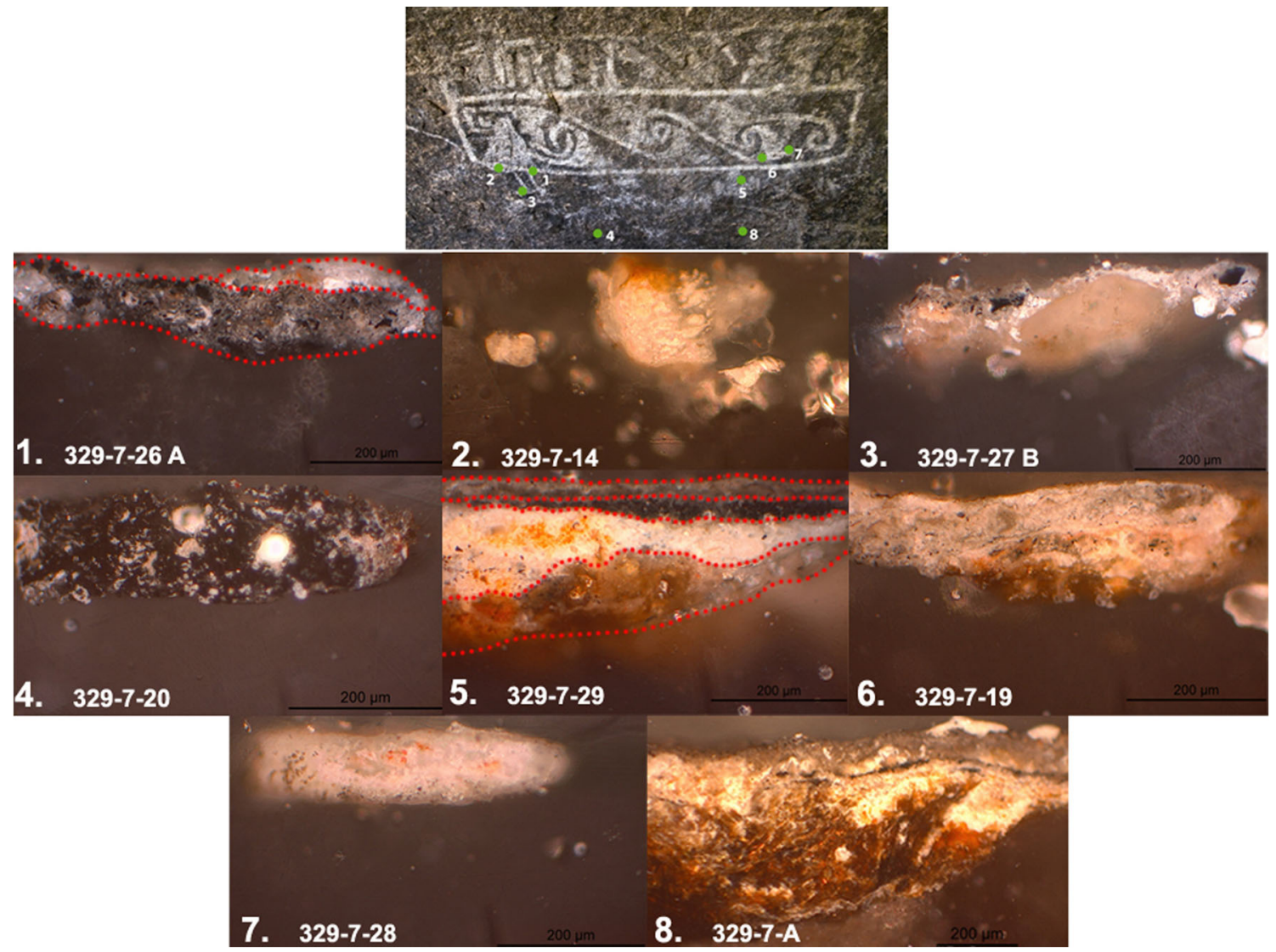

Fig. 7 Rock paintings at panel I of Oyola 7 with the sampled points indicated with green. Below, micro-stratigraphies obtained from the samples studied

the results obtained from the micro-stratigraphies taken at panel I of the cave Oyola 7. This panel presents a rectangular motif painted in white that is overlapped on a design of the same color whose shape reminds a standing bird. Other white figures are arranged below the rectangular motif and some black lines could be interpreted as relicts of ancient motifs, very deteriorated nowadays. As we have seen in previous studies, all these figures are superimposed on two thin layers of soot deposited on the wall as a result of several fires lit in the proximity of the rock and detected in the excavation of the cave (Gastaldi et al. 2016; Lucas Gheco 2017). From this panel, we took 8 samples, particularly from the white paintings and the rock surface with soot (Fig. 7). For the goals of this article, we would like to focus on some of these samples. More information about this panel and the related chemical analyses of the samples can be found elsewhere (Lucas Gheco 2017; Lucas Gheco et al. 2018).

Firstly, sample 5 (329-7-29) was extracted from a white geometric design placed under the rectangular motif (Fig. 7, sample 5). The micro-stratigraphy of this sample shows the presence of, at least, four layers (Fig. 8). Starting from the top and outermost layer, we see a white grayish stratum that could be interpreted as the sampled visible white motif. The Raman analysis of this stratum detects the characteristic bands of gypsum and whewellite, corresponding with high concentration of sulfur and calcium observed in SEM-EDS (Fig. 9). Just below, we detect a black layer whose studies reveal the carbon's Raman bands, with lower concentration of sulfur and a high level of carbon by SEM-EDS. This layer is similar to those that we saw studying the black paintings of the site, mostly with carbon as pigment. However, the presence of soot deposits at the cave, also primarily made of carbon, raises questions about the nature of the stratum. Nevertheless, the morphological differences described above allow us to preliminarily assign this layer as a painting stratum because the layer's thickness (average of $23 \mu \mathrm{m}$ with a standard deviation of $9 \mu \mathrm{m}$ ) presents the values corresponding with the measurements of the black paintings. But, although the morphological measurements present significant differences between soot and painting layers, some variables as the duration of fire, wind orientation, proximity with the wall, between others (Lacanette et al. 2017) could modify the characteristics of the soot deposit, creating a stratum with other morphology, in some cases similar to the black paintings. Hence, until we can advance in this differentiation and carry out experiments, we need other line of evidence to asseverate that this black layer is a hidden painting. 


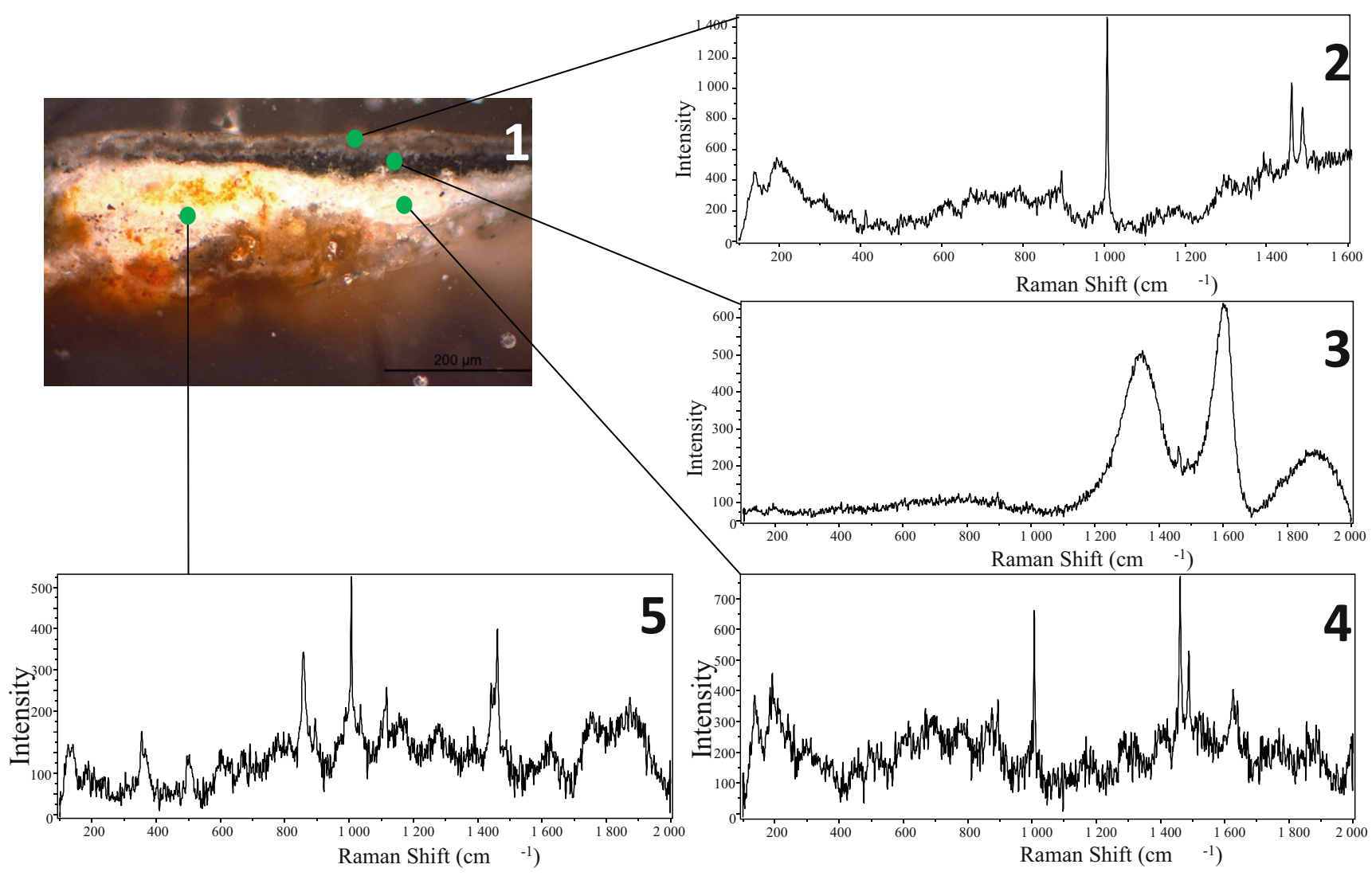

Fig. 8 Raman analyses of sample 5 at panel I of Oyola 7. Each spectrum exposes the characteristic bands of (2) gypsum and whewellite, (3) carbon, (4) gypsum and whewellite, and (5) gypsum and whewellite

A similar situation has been detected in sample 1 (329-7-26) from the same panel (Fig. 7, sample 1, and Fig. 10). This sample was taken from an overlapping between two white paintings. However, the microstratigraphy shows, under a white grayish stratum corresponding to the paintings, another black layer, similar to the one observed in sample 5. The Raman analyses also show the bands of carbon in this layer. The stratum presents an $86.6-\mu \mathrm{m}$ thickness with standard deviation of $16.4 \mu \mathrm{m}$, in agreement with those values corresponding to black painting strata. In this way, the chemical and morphological features of the stratum led us to consider it as an underlying black painting. Moreover, a close photograph taken from the sampled zone reveals, after being processed with D-Stretch (Harman 2008), some traces in black that could be assigned to the remains of an ancient figure, partially superimposed by the white paints (Fig. 11). This point may be another evidence to interpret this black stratum as an underlying figure.

\section{White underlying layers}

Unlike the red and black layers described above, white strata are more usual in the studied samples. They have been detected not only linked with rock paintings but also connected with natural process that produce whitish layers of gypsum, calcium carbonate, clays, among others, described elsewhere for archeological sites (Green et al. 2017; Mahmoud 2012; Prieto et al. 1998; Tomasini et al. 2013). As a consequence, the problem not only lies on the identification of white underlying layers but also in the elucidation of the origin of these strata. However, we could describe an example that displays the potential of the proposed methodology to discover white underlying paintings. Some of the caves at Oyola's site present new inscriptions done with blue aerosol. These graffiti usually are names or phrases but in some cases they present a zoomorphic shape. In one of these blue figures, a camelid, we noticed that some sectors seemed to cover another white painting, whose limits were barely visible. From this observation, a sample from the blue motif was taken. The microstratigraphy obtained exposes the presence of a white layer underlying the blue stratum (Fig. 12). Raman signals of the sample showed bands corresponding to Prussian blue in the first layer and gypsum signals in the whitish underlying stratum. The chemical composition and the morphological aspects of this hidden stratum are similar to the white paintings analyzed in the site. 
Fig. 9 SEM-EDS mapping of sample 5 from panel I of Oyola 7. The images show the concentration of chemical elements $(\mathrm{C}, \mathrm{Fe}, \mathrm{S}, \mathrm{Ca}, \mathrm{Al}, \mathrm{Si}$, and $\mathrm{K})$ in the sample

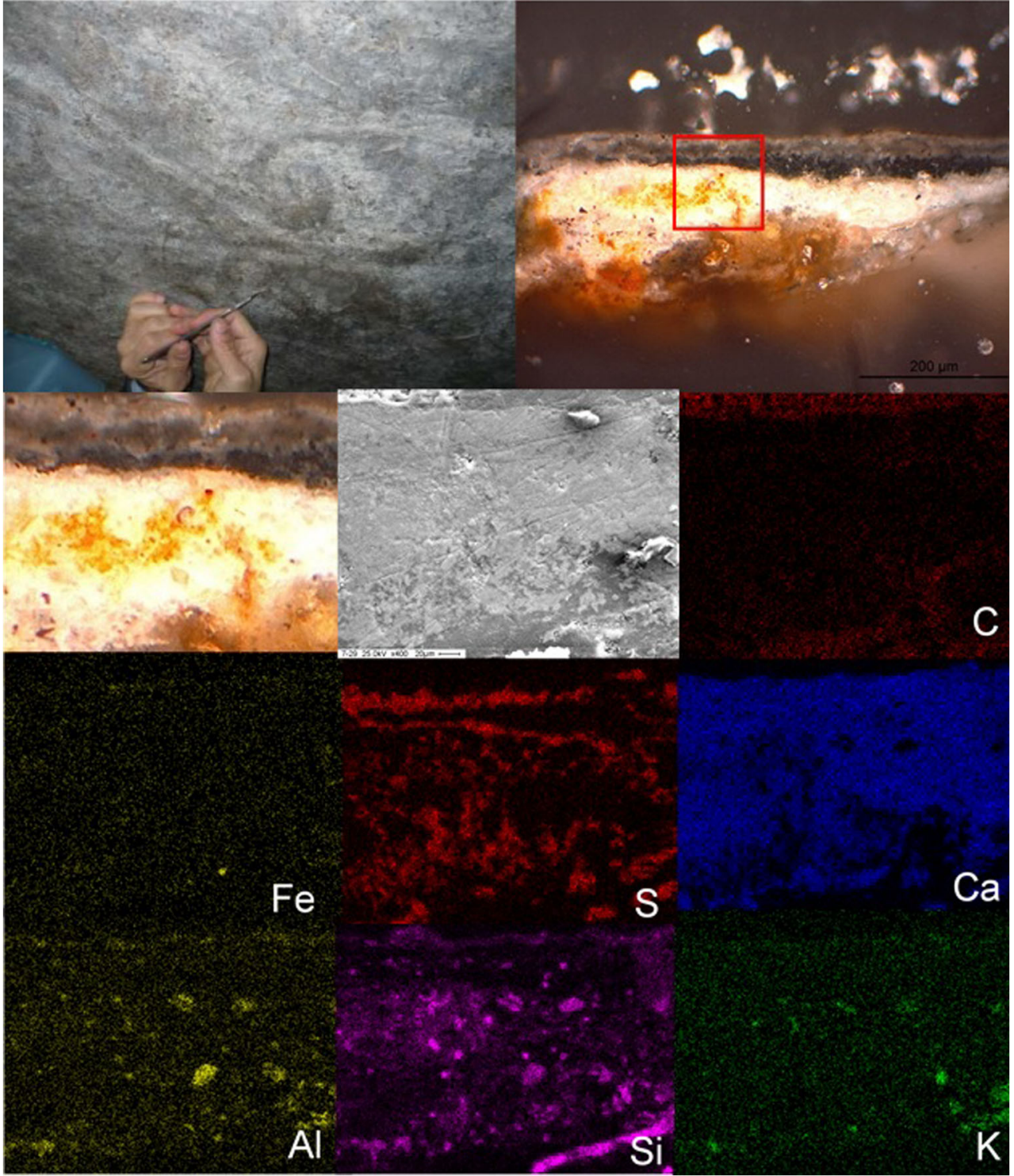

Nevertheless, chemical characterization of the pigment is not enough to determine the cultural or natural origin of the white layer. Thus, additional lines of evidence must be explored. In this case, previous archeological investigations carried on by Amalia Gramajo and Hugo Martínez Moreno in the 1970s and 1980s (Gramajo and Martínez Moreno 1978, 1982) provided a necessary proof for supporting and validating the herein presented methodology. In these articles, the authors documented with black and white photographs the same panel where actually the blue figures are. If we observe the photographs and compare them with new grayscale pictures, we could note several differences (Fig. 13). Firstly, the camelid figure presents morphologic differences. Secondly, the whitish color in the old pictures is changed by a dark color in the new one as a consequence of the transformation of blue color in the black and white image. For these reasons, plus the in situ observations and the micro-stratigraphy evidences, we could propose that under the actual blue graffiti is placed an older white painting.

\section{Discussion}

The examples presented above described an application of a micro-stratigraphic method that allows us to detect, identify, and chemically characterize hidden rock paintings coated by other natural or anthropic layers. This approach is not limited to chemical information but also uses multiple auxiliary lines of evidence such as micro-stratigraphic analysis, morphological observation, and archeological evidences.

Therefore, it is required a detailed discussion about the problems, limits, and potentials of the methodology. First of 
Fig. 10 Raman analysis of sample 1 from panel I of Oyola 7. The spectrum shows the characteristic bands of carbon

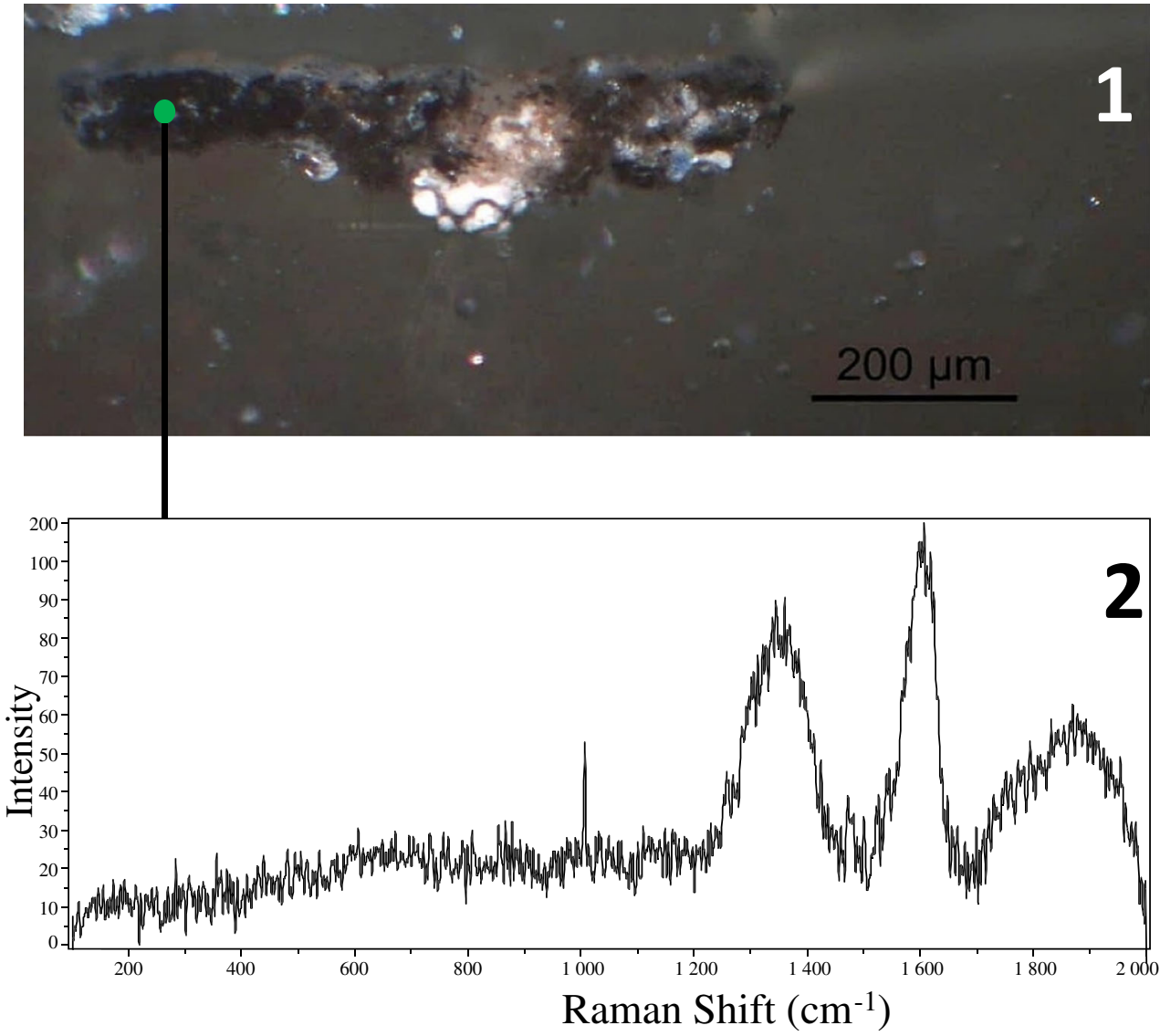

all, it is essential to establish rigorous steps to differentiate between natural and anthropic strata in order to avoid false positives. As it was described for white strata, the presence of natural formations resulting from weathering products (gypsum or calcium carbonate deposits) or biological activity (oxalate crusts, bat guano) produces layers with similar characteristics under the microscope than the painting strata. Additionally, the problem is enlarged by the presence of anthropic deposits not linked with paint activity, such as soot stains, when dealing with black paintings. These issues could be partially solved by a detailed chemical study of the support rock and its deterioration processes in order to generate a chemical and morphological profile of the "blank" wall (G.
Mauran et al. 2018). In this specific case, XRD, FT-IR, and XRF bulk analyses along with micro-stratigraphic studies (Raman and SEM-EDS) of blank wall samples from rock shelters were processed and analyzed. These studies confirmed the presence of gypsum and calcium oxalate layers as well as black soot deposits. However, no potential interferences were found for red paintings which, in this case, are exclusively made of hematite. Having this in mind, the detection of subjacent layers with similar chemical composition than the paintings requires other lines of evidence in order to confirm the hypothesis. As an example, in the case of black paintings, the morphological studies performed to discriminate carbon soot strata from black paintings, especially by
Fig. 11 Left, close photo of the zone where we took sample 1 of panel I (point green). Right, photo digitally enhanced with D-Stretch (YBK). Note the black traces just under the grayish sampled paintings
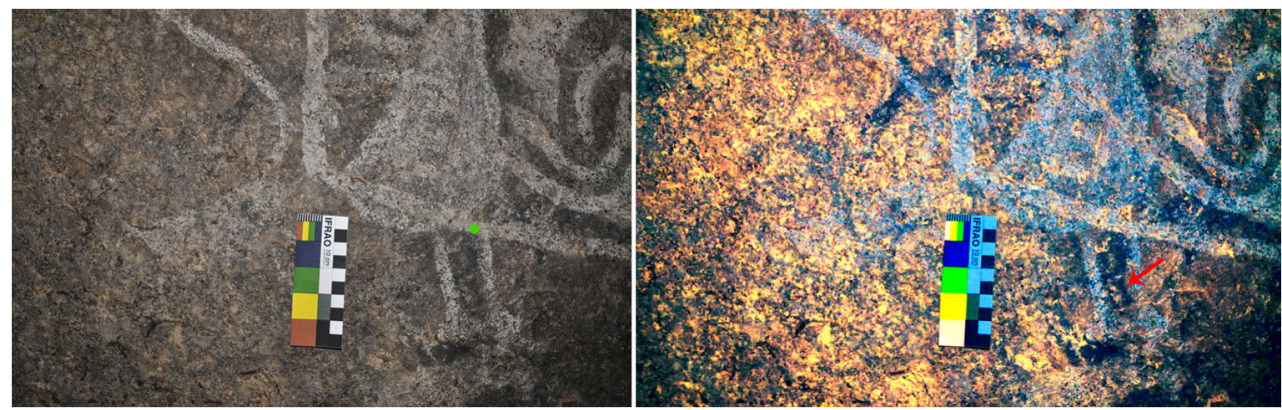

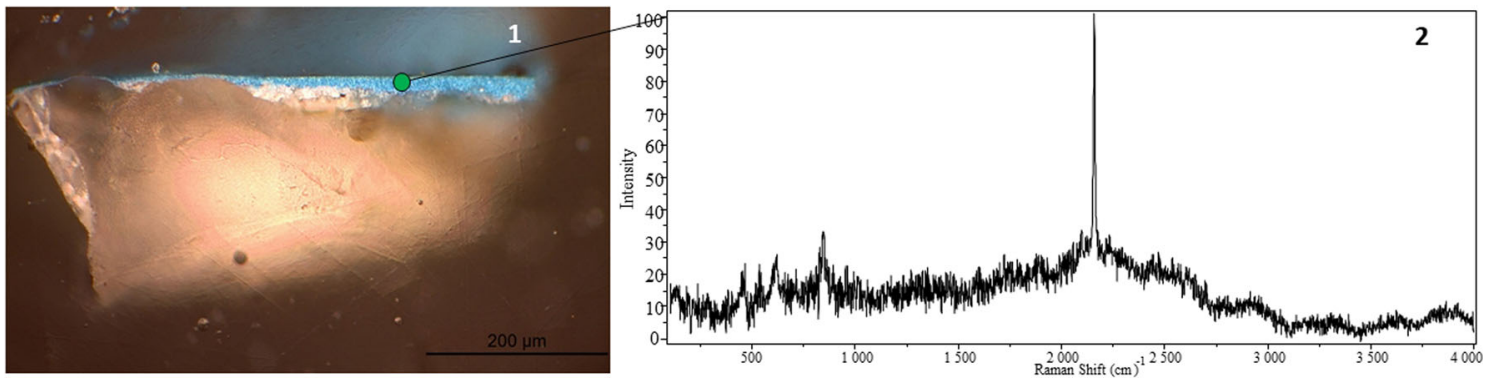

Fig. 12 Raman analysis of sample 329-7-12 of Oyola 7. The spectrum shows the signals corresponding to the Prussian blue

measuring layer thickness and homogeneity, can be very helpful. However, new studies must be done to improve this technique and explore others like the organic characterization of possible binders which should be present only in paintings.

Another challenge in applying this method is linked with the conservation of the caves. Although micro-destructive, the methodology constitutes a source of deterioration of the rock art. Therefore, we propose that this method should be understood as a screening method that must be continued and deepened by non-invasive techniques. Additionally, this method may reuse samples taken for other original purposes (i.e., paintings characterization, support rock studies, etc.) and focus the attention on the underlying layers usually not studied in detail. In this way, by this method, we could detect and characterize hidden paintings, whose extension and shape must be explored with non-invasive techniques. The extension and shape of the hidden motif is also a key factor for further interpretation, so the development of these techniques will be an important goal for future works.

Despite the limitations, it is important to remark the advantages as well as the originality of the proposed method. Firstly, we are able to explore hidden episodes of the painting history of caves. This possibility opens up a new way to investigate the complexity of rock art and its historical processes of construction, transformation, and reuse. Secondly, beyond the detection of underlying paintings, we could study the morphology and extension of natural deposits formed above the figures and reach important interpretations. For instance, while paintings coated by thick layers of gypsum or whewellite are attributed to the result of a slow covering by natural degradation agents, thin layers are potentially correlated to anthropic actions during in brief periods of time.

These two new lines of evidence have remarkable consequences on the understanding of the history of
Fig. 13 Above: grayscale photographs of the zone where sample 329-7-12 was taken at Oyola 7. a Photograph published by Amalia Gramajo y Hugo Martínez Moreno in 1978. b Photograph published by Amalia Gramajo y Hugo Martínez Moreno in 1982. Below: photographs of the present condition of the panel. c Grayscale photograph (2015). d Color photograph (2015)

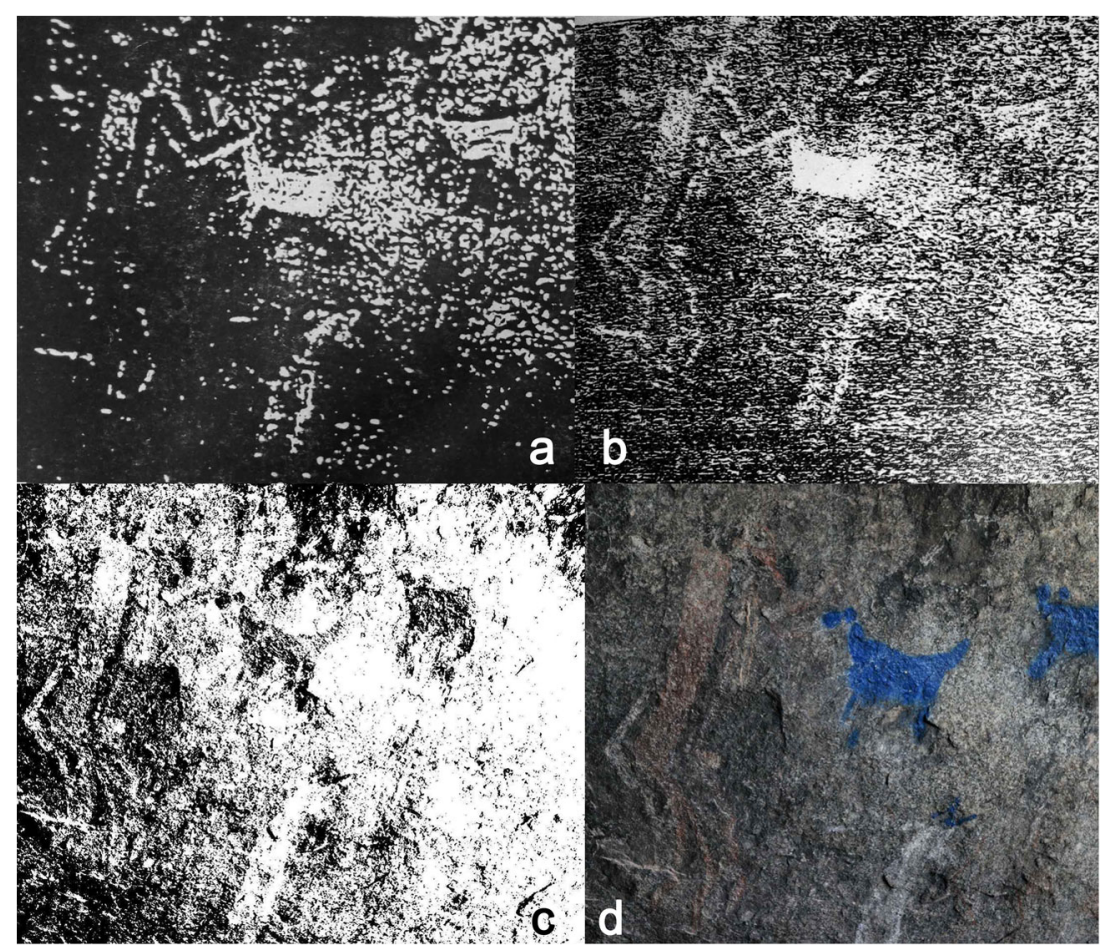


rock paintings at Oyola, interpreted almost exclusively as the results of La Aguada culture. Although we do not have an absolute chronology of all history, the hidden paintings identified below La Aguada figures allow us to propose earlier stages of rock art production. In some cases, these underlying strata were separate from La Aguada motifs by thick natural deposits of calcium oxalates or gypsum slowly formed, so it could be a signal of the temporal distance between each paint event. Similarly, other episodes of paint production have been localized overlapping La Aguada figures, showing that the history of the painted caves of Oyola has a complexity that exceeds one culture and shows many events of occupation and paint making.

Finally, it is important to place the micro-stratigraphic method in a more general context linked also with chronology of rock art. Nowadays, new techniques of absolute dating are explored, some of them combining the study of paintings micro-stratigraphy's with AMS $\mathrm{C}^{14}$, thermoluminescence, or uranium/thorium dating (Bonneau et al. 2017; Ferrier et al. 2014, 2015; García-Diez et al. 2013; D. L. Hoffmann et al. 2018; Dirk L Hoffmann et al. 2016; Pearce and Bonneau 2018; Pike et al. 2016). In addition, the proposed method not only allows us to discover underlying paintings but also provides a relative chronology of the mural painting, possible to be correlated against the archeological excavation containing absolute dates (L. Gheco et al. 2017; Tascon et al. 2016). In this way, the construction of a chronology of the wall history by correlation with excavation data and vice versa becomes feasible.

\section{Conclusions}

In this work, a methodology was proposed that combines micro-stratigraphic observations with chemical studies and other lines of evidence such as morphological and documental investigations in order to discover and characterize hidden rock paintings. Beyond the limitations thoroughly discussed, this method allows us to detect red, white, and black underlying paints. The latter can be either covered by other natural or anthropic layers. To this end, the investigation herein presented offers enough tools to have access to a lost history eclipsed by different events that currently are not visible. In this way, this work proposes a method to reach a new dimension of rock art research, considering the painted murals as a threedimensional object instead of a flat surface.

In this context, the current archeological research, especially in rock art studies, widely uses archaeometric analysis, and this trend has increased in the recent years (Kristiansen 2017; Sørensen 2017). Many of these studies make use of microstratigraphic samples as a key tool to understand the chemical composition of the paintings. However, the micro- stratigraphic approach proposed combined with chemical and morphological studies have a strong potential that exceeds the classic paint mixture characterization. This fact allows us to explore a wide range of topics that goes from relative chronology of rock art to the absolute dating of the paintings and the complexity of rock art making and meanings. Although it is a micro-destructive technique, the method must be understood as an exploration step that should be continued and deepened by non-invasive strategies. In agreement with actual tendencies in archeology that highlight the importance of looking into the historical processes of production and transformation of the archeological objects and places (Moore 2010; Pauketat 2001; Pauketat and Alt 2005), the methodology described gathers new insights into the history of rock art, not only as the flat disposition of figures but also as the result of multiple painting events and different persons, times, and meanings. This approach to rock art understood as a threedimensional object exposes the complexity of human behavior, the agent's elections, and their transformations through the time.

Acknowledgments Research was founded by Consejo Nacional de Investigaciones Científicas y Técnicas, Agencia Nacional de Promoción Científica y Tecnológica (PICT 2017-2462 y PICT 2017-2589), Secretaría de Ciencia y Técnica (Universidad Nacional de Catamarca), and Instituto de Investigaciones sobre el Patrimonio Cultural (IIPCTAREA, Universidad Nacional de San Majrtín). The authors specially thank all the research team members that participated in the field and laboratory studies.

\section{References}

Bonneau A, Pearce D, Mitchell P, Staff, R, Arthur C, Mallen L et al (2017) The earliest directly dated rock paintings from southern Africa: new AMS radiocarbon dates. Antiquity 91(356):322-333. https://doi.org/10.15184/aqy.2016.271

Chiriu D, Ricci PC, Polcaro A, Braconi P, Lanzi D, Nadali D (2014) Raman study on calcium hydroxide used on the surface of Pompeii pottery Abstract. J Spectrosc 14:1

De la Fuente N, Nazar DC, Pelli E (2005) Documentación y diagnóstico del arte rupestre de La Tunita, Provincia de Catamarca, República Argentina. In: de la V CO, de la C M, de A. y su D. La (eds) La Cultura de La Aguada y sus Expresiones Regionales. EUDELAR, La Rioja, pp 227-244

Edwards HGM, Russell NC, Seaward MRD (1997) Calcium oxalate in lichen biodeterioration studied using FT-Raman spectroscopy. Spectrochim Acta A Mol Biomol Spectrosc 53(1):99-105. https:// doi.org/10.1016/S1386-1425(97)83013-2

Edwards HGM, Newton EM, Russ J (2000) Raman spectroscopic analysis of pigments and substrata in prehistoric rock art. J Mol Struct 550-551:245-256. https://doi.org/10.1016/S0022-2860(00)003896

Feliu M \& Martínez-Brell P (2008). Evolución química de materiales pictóricos: degradación o conservación. In M. y R. Llorens, 
García- Heras (Ed.), Actas del VII Congreso Ibérico de Arqueometría. Madrid

Ferrier C, Debard É, Kervazo B, Brodard A, Guibert P, Baffier D et al (2014) Les parois chauffées de la grotte Chauvet-Pont d?Arc (Ardèche, France): caractérisation et chronologie. Paleo 25:59-78

Ferrier C, Debard É, Kervazo B, Brodard A, Guibert P, Baffier D et al (2015) Heated walls of the cave Chauvet-Pont d'Arc heated walls of the cave Chauvet-Pont d'Arc (Ardèche, France): characterization and chronology. Paleo 25(June 2016:0-25

Fredlund G, Sundstrom L (2007) Digital infra-red photography for recording painted rock art. Antiquity 81(313):733-742. https://doi. org/10.1017/S0003598X00095697

García-Diez M, Hoffmann DL, Zilhão J, Heras C d 1, Lasheras JA, Montes R, Pike AWG (2013) Uranium series dating reveals a long sequence of rock art at Altamira Cave (Santillana del Mar, Cantabria). J Archaeol Sci 40(11):4098-4106. https://doi.org/10. 1016/j.jas.2013.05.011

Gastaldi M, Gheco L, Moreno E, Granizo G, Ahumada M, Egea D, Quesada M (2016) Primeros resultados de las excavaciones estratigráficas en Oyola 7 (Sierra de El Alto-Ancasti, provincia de Catamarca, Argentina). Comechingonia 20(2):73-104

Gheco L (2012). Una historia en la pared. Hacia una visión diacrónica del arte rupestre de Oyola. Tesis de Licenciatura inédita: Universidad Nacional de Catamarca. San Fernando del Valle de Catamarca

Gheco L (2017). El laberinto de las paredes pintadas. Una historia de los abrigos con arte rupestre de Oyola, Catamarca. Tesis Doctoral inédita: Universidad Nacional de Córdoba. Córdoba, Argentina.

Gheco L, Poliszuk A (2015) Caracterización química de pinturas rupestres prehispánicas del sitio arqueológico de Oyola mediante sem-eds, drx, ft-ir, frx y gc-ms (Catamarca, Argentina). In: Pifferetti AA, Dosztal I (eds) Arqueometría argentina, metodologías científicas aplicadas al estudio de los bienes culturales: datación, caracterización, prospección y conservación. Aspha, Buenos Aires, pp 271-284

Gheco L \& Quesada M (2012). El arte rupestre de Oyola (dpto. El Alto, Catamarca): un caso de narrativas superpuestas. Aportes científicos desde Humanidades (UNCa), 9, 228-244. Facultad de Humanidades, UNCa. San Fernando del Valle de Catamarca

Gheco LI, Quesada MN, Ybarra G, Poliszuk A \& Burgos O (2013). Espacios rupestres como «obras abiertas»: una mirada a los procesos de confección y transformación de los abrigos con arte rupestre del este de Catamarca (Argentina). Revista Española de Antropología Americana, 43(2). https://doi.org/10.5209/rev_REAA.2013.v43.n2. 44014

Gheco L, Gastaldi M, Marte F, Quesada M, Tascon M, Mastrangelo N (2017) About fires and paintings: three stratigraphic insights on the history of a cave with prehispanic rock art. J Archaeol Sci Rep 15: 48-58. https://doi.org/10.1016/j.jasrep.2017.07.009

Gheco L, Gastaldi M, Mastrangelo N, Quesada M, Marte F, Tascon M (2018) Entre humos, fuegos y pinturas. Una metodología para conectar historias sobre una cueva con arte rupestre del sitio de Oyola. Boletín del Museo Chileno de Arte Precolombino, In press, Catamarca, Argentina

González AR (1998) Cultura La Aguada. Arqueología y diseños. Filmediciones Valero, Buenos Aires

Gordillo I, Baldini M, Kusch F (2000) Entre objetos, rocas y cuevas: significados y relaciones entre la iconografía rupestre y mobiliar de Aguada. In: Podestá MM, de Hoyos M (eds) Arte en las Rocas. Arte Rupestre, Menhires y Piedras de Colores en Argentina. Sociedad Argentina de Antropología, Buenos Aires, pp 101-111

Gramajo A, Martínez Moreno H (1978) Otros Aportes al Arte Rupestre del Este Catamarqueño. Antiquitas XXVI-XXVII:12-17

Gramajo A, Martínez Moreno H (1982) Otros aportes al arte rupestre del este catamarqueño. Estudio Museo arqueológico Emilio y Duncan Wagner 3:77-88
Green H, Gleadow A, Finch D, Hergt J, Ouzman S (2017) Mineral deposition systems at rock art sites, Kimberley, Northern Australia field observations. J Archaeol Sci Rep 14(August:340-352. https:// doi.org/10.1016/j.jasrep.2017.06.009

Harman J (2008). Using decorrelation stretch to enhance rock art images. http://www.dstretch.com/DStretchHandout.pdf. 06-2018

Hernanz A, Gavira-Vallejo JM, Ruiz-López JF (2007) Calcium oxalates and prehistoric paintings. The usefulness of these biomaterials. J Optoelectron Adv Mater 9(3):512-521

Hernanz A, Gavira-Vallejo JM, Ruiz-López JF, Edwards HGM (2008) A comprehensive micro-Raman spectroscopic study of prehistoric rock paintings from the Sierra de las Cuerdas, Cuenca, Spain. J Raman Spectrosc 39(April:972-984. https://doi.org/10.1002/jrs

Hernanz A, Ruiz-López JF, Madariaga JM, Gavrilenko E, Maguregui M, De Vallejuelo SFO et al (2014) Spectroscopic characterisation of crusts interstratified with prehistoric paintings preserved in openair rock art shelters. J Raman Spectrosc 45(11-12):1236-1243. https://doi.org/10.1002/jrs.4535

Hernanz A, Iriarte M, Bueno-Ramírez P, De Balbín-Behrmann R, GaviraVallejo JM, Calderón-Saturio D et al (2016) Raman microscopy of prehistoric paintings in French megalithic monuments. J Raman Spectrosc 47(5):571-578. https://doi.org/10.1002/jrs.4852

Hill C (1982) Origin of black deposits in caves. Bull Natl Speleol Soc 44(1):15-19

Hoffmann DL, Pike AWG, Garcia-Diez M, Pettitt PB, Zilhao J (2016) Methods for U-series dating of $\mathrm{CaCO} 3$ crusts associated with Palaeolithic cave art and application to Iberian sites. Quat Geochronol 36:104-119. https://doi.org/10.1016/j.quageo.2016.07. 004

Hoffmann DL, Standish CD, García-Diez M, Pettitt PB, Milton JA, Zilhão J, Alcolea-González JJ, Cantalejo-Duarte $\mathrm{P}$, Collado $\mathrm{H}$, de Balbín R, Lorblanchet M, Ramos-Muñoz J, Weniger GC, Pike AWG (2018) U-Th dating of carbonate crusts reveals Neandertal origin of Iberian cave art. Science 359(6378):912-915. https://doi. org/10.1126/science.aap 7778

Kristiansen K (2017) The nature of archaeological knowledge and its ontological turns. Nor Archaeol Rev (00,00):1-4. https://doi.org/ 10.1080/00293652.2017.1372802

Lacanette D, Mindeguia JC, Brodard A, Ferrier C, Guibert P, Leblanc JC, Malaurent P, Sirieix C (2017) Simulation of an experimental fire in an underground limestone quarry for the study of Paleolithic fires. Int J Therm Sci 120(October:1-18. https://doi.org/10.1016/j. ijthermalsci.2017.05.021

Mahmoud HHM (2012) Morphological, chemical and mineralogical characterization of deterioration products from the tomb of Kheruef (TT192), (Luxor, Egypt). PERIODICOdi MINERALOGIA 81(1):131-143. https://doi.org/10.2451/ 2012PM0008

Marte F, Mastrangelo N, Tascon M (2011) The art of measuring: optical microscopy applied to the measurement of transversal sections. Eadem Utraque Europa 13:257-268

Marte F, Tascón M, Mastrangelo N (2013) The art of measuring II: challenges in measuring particles in cross-sections. Eadem Utraque Europa 14:245-254

Mauran G, Bassel L, Ferrier C, Lacanette D, Bousquet B, Chapoulie R (2018) Variability and sampling strategy of cave wall concretion: case study of the moonmilk found in Leye Cave (Dordogne). Archaeometry, (September 61:327-341. https://doi.org/10.1111/ $\operatorname{arcm} .12434$

Mauran G, Lebon M, Détroit F, Caron B, Nankela A, Pleurdeau D \& Bahain $J$ (2019). First in situ pXRF analyses of rock paintings in Erongo, Namibia: results, current limits, and prospects. Archaeol Anthropol Sci https://doi.org/10.1007/s12520-019-00787-7

Medina-Alcaide MA (2015) Indicios de iluminación prehistórica en el contexto arqueológico interno de las cuevas decoradas: tipos y potencial arqueológico. In: Giraldo HC, Arranz JJG (eds) En torno 
al arte: el contexto arqueológico interno de las cuevas decoradas. Actas XIX International Rock art Conference (IFRAO 2015). ARKEOS, Tomar

Moore JD (2010) Making a huaca: memory and praxis in prehispanic far northern Peru. J Soc Archaeol 10(3):398-422. https://doi.org/10. $1177 / 1469605310381550$

Pauketat TR (2001) Practice and history in archaeology: an emerging paradigm. Anthropological Theory 1(73):73-98. https://doi.org/10. $1177 / 1469962002002002628$

Pauketat TR, Alt SM (2005) Agency in a postmold? Physicality and the archaeology of culture-making. J Archaeol Method Theory 12(3): 213-237. https://doi.org/10.1007/s10816-005-6929-9

Pearce DG, Bonneau A (2018) Trouble on the dating scene. Nature Ecology and Evolution 2(6):925-926. https://doi.org/10.1038/ s41559-018-0540-4

Pike AWG, Hoffmann DL, Pettitt PB, García-Diez M, Zilhão J (2016) Dating Palaeolithic cave art: why U-Th is the way to go. Quat Int 432:41-49. https://doi.org/10.1016/j.quaint.2015.12.013

Prieto B, Seaward MRD, Edwards HGM, Rivas T, Silva B (1998) An Fourier transform-Raman spectroscopic study of gypsum neoformation by lichens growing on granitic rocks. Spectrochim Acta A Mol Biomol Spectrosc 55(1):211-217. https://doi.org/10. 1016/S1386-1425(98)00245-5

Quesada M, Gheco L (2015) Tiempos, cuevas y pinturas. Reflexiones sobre la policronía del arte rupestre de Oyola (Provincia de Catamarca, Argentina). Relaciones de la Sociedad Argentina de Antropología 2(XL):455-476

Quesada Martínez E (2010) Aplicación Dstretch del software Image-J. Avance de resultados en el Arte Rupestre de la Región de Murcia. Cuadernos de Arte Rupestre 5(May 2008):14-47 http://www. museosdemurcia.com/rupestre/cuadernos/images/6/ QuesadaCAR2008_6_2.pdf 06-2018

Quesada M, Zuccarelli V, Gheco L, Gastaldi M, Boscatto S (2016) Paisaje y experiencia en Oyola a finales del primer milenio D.C. (Dpto. El Alto, Catamarca). Comechingonia 20(2):13-42

Roberts A, Campbell I, Pring A, Bell G, Watchma A, Filcoff RSP et al (2015) A multidisciplinary investigation of a rock coating at Ngaut Ngaut (Devon Downs), South Australia. Aust Archaeol 80(80):3239

Ruiz JF, Hernanz A, Armitage RA, Rowe MW, Viñas R, Gavira-Vallejo JM, Rubio A (2012) Calcium oxalate AMS 14C dating and chronology of post-Palaeolithic rock paintings in the Iberian Peninsula. Two dates from Abrigo de los Oculados (Henarejos, Cuenca, Spain). J Archaeol Sci 39(8):2655-2667. https://doi.org/10.1016/j.jas.2012. 02.038

Russ J, Kaluarachchi WD, Drummond L, Edwards HGM (1999) The nature of a Whewellite-rich rock crust associated with pictographs in southwestern Texas. Stud Conserv 44(2):91. https://doi.org/10. $2307 / 1506721$
Šebela S, Miler M, Skobe S, Torkar S, Zupančič N (2015) Characterization of black deposits in karst caves, examples from Slovenia. Facies 61(2). https://doi.org/10.1007/s10347-015-0430-z

Segura Á (1988). El Arte Rupestre del Este de Catamarca. Las Pictografías de la Candelaria. Dpto. Ancasti, Provincia de Catamarca. Editorial universitaria. Universidad Nacional de Catamarca. Argentina

Sørensen TF (2017) The two cultures and a world apart: archaeology and science at a new crossroads. Nor Archaeol Rev 50(2):101-115. https://doi.org/10.1080/00293652.2017.1367031

Steelman KL, Rowe MW, Boutton TW, Southon JR, Merrell CL, Hill RD (2002) Stable isotope and radiocarbon analyses of a black deposit associated with pictographs at Little Lost River Cave, Idaho. J Archaeol Sci 29(10):1189-1198. https://doi.org/10.1006/jasc.2001. 0791

Tascon M, Mastrangelo N, Gheco L, Gastaldi M, Quesada M, Marte F (2016) Micro-spectroscopic analysis of pigments and carbonization layers on prehispanic rock art at the Oyola's caves, Argentina, using a stratigraphic approach. Microchem J 129:297-304. https://doi.org/ 10.1016/j.microc.2016.07.003

Tomasini EP, Basile M, Ratto N, Maier MS (2013) Evidencias Químicas De Deterioro Ambiental En Manifestaciones Rupestres: Un Caso De Estudio Del Oeste Tinogasteño (Catamarca, Argentina). Boletín del museo chileno de arte precolombino 17(1091):27-38

Trujillo J, Falgueres C, Oosterbeek L, \& Rosina P (2010). Archaeometry of rock art paintings: La Piedra De La Cuadricula (Soacha, Cundinamarca, Colombia). A contribution to the study of prehistoric art. Annali dell'Università di Ferrara, 6, 175-186

Vandevelde S., Brochier J, Desachy B, Petit C, \& Slimak (2017a). Sooted concretions: a new micro-chronological tool for high temporal resolution archaeology. Quaternary International. https://doi.org/10. 1016/j.quaint.2017.10.031

Vandevelde S, Brochier J, Petit C, Slimak L (2017b) Establishment of occupation chronicles in Grotte Mandrin using sooted concretions: rethinking the middle to upper Paleolithic transition gol e. J Hum Evol 112:70-78. https://doi.org/10.1016/j.jhevol.2017.07.016

Watchman AL (1991) Age and composition of oxalate-rich crusts in the Northern Territory, Australia. Stud Conserv 36(1):24. https://doi. org/10.2307/1506449

Zupančič N, Šebela S, Miler M (2011) Mineralogical and chemical characteristics of black coatings in Postojna Cave system. Acta Carsologica 40(2):307-317. https://doi.org/10.3986/ac.v40i2.15

Publisher's note Springer Nature remains neutral with regard to jurisdictional claims in published maps and institutional affiliations. 